Commentary Open Access \title{
Role of clinical evaluation committees in sepsis trials: from 'valid cohort' assessment to subgroup analysis
}

\author{
Jean-François Dhainaut
}

\author{
Université Paris Descartes, Service de réanimation Médicale, Hôpital Cochin, 75014 Paris, France \\ Corresponding author: Jean-François Dhainaut, dhainaut@aeres-evaluation.fr \\ Published: 18 Mar 2009
}

Critical Care 2009, 13:124 (doi:10.1186/cc7686)

This article is online at: http://ccforum.com/content/13/2/124

(c) 2009 BioMed Central Ltd

See related research by Laterre et al., http://ccforum.com/content/13/2/R36

\begin{abstract}
In this issue of Critical Care, the study from Laterre and colleagues offers suggestions for the role of clinical evaluation committees (CECs) in future sepsis trials. Despite encouraging preliminary results, all randomized controlled trials (RCTs) devoted to potential compounds in severe sepsis have failed to show survival benefit. One of the reasons might be related to RCT-related factors that inevitably occur within a heterogeneous septic patient population. A patient population free from confounding events would seem to provide the most suitable platform upon which to judge therapeutic effect. To solve this issue, CECs have been introduced into RCTs in sepsis to ensure uniform data for analysis and to identify such 'optimal cohorts' for which the therapy was initially designed to treat. More recently, some RCTs have reported positive results
\end{abstract}

in sepsis. The role of CECs has shifted to become a more integral part of the detailed analysis of drug safety and efficacy in large databases, and to identify subgroups of patients in which a therapy might be less or more effective and/or safe. As an example, the retrospective analysis by Laterre and colleagues focuses on patients with severe community-acquired pneumonia (sCAP) within a large, failed RCT (on recombinant tissue factor pathway inhibitor (rTFPI)). However, the results should be interpreted with great caution, and should be viewed as exploratory and a hypothesis-generating activity. This question of potential benefit of rTFPI in patients with sCAP will be definitively answered by the results of the recently completed RCP.
The study from Laterre and colleagues [1], published in this issue of Critical Care, offers suggestions for the role of clinical evaluation committees (CECs) in future sepsis trials. From 1990 to 2000, randomized controlled trials (RCTs) have evaluated a variety of potential therapeutic interventions for severe sepsis. Despite some encouraging results in phase II trials, all RCTs have failed to show survival benefit based upon intention-to-treat analyses [2]. The reasons for these disappointing results might not only reflect the possible lack of efficacy of each new therapy, but may also be related to RCT-related factors that inevitably occur within a heterogeneous septic patient population. Other variables that might occur include variability of medical management strategies and the frequency of protocol violations. Phase II trials use a small number of highly motivated and experienced centers that are less susceptible to confounding events brought about by variations in clinical practices than international RCTs.
A patient population free from confounding events and studied in full compliance with the protocol, including strict adherence to entry criteria, would seem to provide the most suitable platform upon which to judge the therapeutic effect of a new intervention for sepsis. To solve this issue, CECs have been introduced into RCTs in sepsis [3-7] to ensure uniform data for analysis and to identify such 'optimal cohorts' for which the therapy was initially designed to treat. As an example, Sprung and colleagues [8] showed that the reduction of mortality was higher in the pre-specified valid cohort than in the overall intent-to-treat study population (26.5 versus 14.5\%) when using anti-tumor necrosis factor antibodies for sepsis.

More recently, some RCTs have reported positive results in sepsis $[9,10]$, although these results remain the subject of much debate [11]. Consequently, the role of CECs has shifted to become a more integral part of the detailed analysis of drug 
safety and efficacy in large international integrated databases of several trials [12], and to identify subgroups of patients in which the therapy might be less [13] or more [14] effective and/or safe.

As an example, the retrospective review of patient subgroups reported by Laterre and colleagues [1] is of great interest. They focus on patients comprising a well defined population at high risk of death from severe community-acquired pneumonia (sCAP) within a large, failed RCT on recombinant tissue factor pathway inhibitor (rTFPI) in severe sepsis. The heterogeneity related to sources of infection, microorganisms, surgical procedures and risk of bleeding is considerably reduced in SCAP when compared to the broad, non-selected, severe sepsis population.

However, as the authors stress, results from small groups of retrospectively selected patients should be interpreted with great caution due to a combination of reduced statistical power, increased variance, multiplicity, and the play of chance; therefore, these results should be viewed only as exploratory and a hypothesis-generating activity. For instance, the significant reduction of mortality with rTFPI observed in the subgroup of SCAP without heparin seems more related to the unexpected high mortality of the placebo group (51.9\%) than to a low mortality in the treated group (29.3\%). This finding is in agreement with the higher mortality observed in patients on usual-care heparin at baseline who were randomized to placebo than those randomized to heparin in the XPRESS trial assessing the effect of prophylactic heparin in patients with severe sepsis treated with activated protein C [15].

This question of potential benefit of rTFPI in patients with SCAP will be definitively answered by the results of the recently completed phase III CAPTIVATE trial.

\section{Competing interests}

J-FD has participated in advisory boards and received lecture fees from Eli Lilly and Novartis.

\section{References}

1. Laterre PF, Opal SM, Abraham E, Larosa SP, Creasey AA, Xie F, Poole L, Wunderink RG: A clinical evaluation committee assessment of recombinant human tissue factor pathway inhibitor (Tifacogin) in patients with severe communityacquired pneumonia. Crit Care 2009, 13:R36.

2. Opal SM, Cross AS: Clinical trials for severe sepsis. Past failures, and futures hopes. Infect Dis Clin North Am 1999, 13:285-297.

3. Ziegler EJ, Fisher CJ Jr, Sprung CL, Straube RC, Sadoff JC, Foulke GE, Wortel CH, Fink MP, Dellinger RP, Teng NN, et al:: Treatment of Gram-negative bacteremia and septic shock with HA-1A human monoclonal antibody against endotoxin. $N$ Engl J Med 1991, 234:429-436.

4. Dhainaut JF, Tenaillon A, Le Tulzo Y, Schlemmer B, Solet JP, Wolff M, Holzapfel L, Zeni F, Dreyfuss D, Mira JP, et al.: Platelet-activating factor antagonist BN 52021 in the treatment of severe sepsis. A randomized, double-blind, placebo-controlled multicenter trial. Crit Care Med 1994, 22:1720-1728.

5. Abraham E, Wunderink R, Silverman H, Perl TM, Nasraway S, Levy $\mathrm{H}$, Bone R, Wenzel RP, Balk R, Allred R, et al.: Efficacy and safety of monoclonal antibody to human tumor necrosis factor alpha in patients with sepsis syndrome. A randomized, controlled double-blind, placebo-controlled trial. JAMA 1995, 273:934-941.

6. Opal SM, Fisher CJ Jr, Dhainaut JF, Vincent JL, Brase R, Lowry SF, Sadoff JC, Slotman GJ, Levy H, Balk RA, Shelly MP, Pribble JP, LaBrecque JF, Lookabaugh J, Donovan H, Dubin H, Baughman R, Norman J, DeMaria E, Matzel K, Abraham E, Seneff M: Confirmatory interleukin-1 receptor antagonist trial in severe sepsis: a phase III, randomized, controlled double-blind, placebo-controlled trial. Crit Care Med 1997, 25:1115-1124.

7. Panacek EA, Marshall J, Albertson T, et al.: Effect of a clinical evaluation committee explicit review on classification of patients and prediction of mortality in the MONARCS sepsis trial. Crit Care Med 2000, 28:A197.

8. Sprung CL, Finch RG, Thijs LG, Glauser MP: International sepsis trial (INTERSEPT): role and impact of a clinical evaluation committee. Crit Care Med 1996, 24:1441-1447.

9. Bernard GR, Vincent JL, Laterre PF, LaRosa SP, Dhainaut JF, Lopez-Rodriguez A, Steingrub JS, Garber GE, Helterbrand JD, Ely EW, Fisher CJ Jr, Recombinant human protein C Worldwide Evaluation in Severe Sepsis (PROWESS) study group: Efficacy and safety of recombinant human activated protein $\mathrm{C}$ for severe sepsis. N Engl J Med 2001, 344:699-709.

10. Annane $D$, Sebille V, Charpentier C, Bollaert PE, François $B$, Korach JM, Capellier G, Cohen Y, Azoulay E, Troché G, ChaumetRiffaud $P$, Bellissant $E$ : Effects of treatment with low doses of hydrocortisone and fludrocortisone of mortality of patients with septic shock. JAMA 2002, 288:862-871.

11. Eichaker PQ, Danner RL, Suffredini AF, Cui X, Natanson C: Reassessing recombinant human activated protein $C$ for sepsis: time for a new randomized controlled trial. Crit Care 2005, 33:2426-2428.

12. Dhainaut JF, INDEPTH clinical evaluation Committee: International integrated database for the evaluation of severe sepsis (INDEPTH): clinical evaluation committee report on the safety of drotrecogin alfa (activated). Curr Med Res Opin 2008, 24:1187-1197.

13. Payen D, Sablotzki A, Barie PS, Ramsay G, Lowry S, Williams M, Sarwat $S$, Northrup J, Toland $P$, Booth FV: International integrated database for the evaluation of severe sepsis and drotrecogin alfa (activated therapy: analysis of efficacy and safety data in a large surgical cohort. Surgery 2007, 141:548-561.

14. Laterre PF, Garber G, Levy H, Wunderink R, Kinasewitz GT, Sollet JP, Maki DG, Bates B, Yan SC, Dhainaut JF, PROWESS Clinical Evaluation Committee: PROWESS clinical evaluation committee. Severe community-acquired pneumonia as a cause of severe sepsis: data from the PROWESS study. Crit Care Med 2005, 33:952-961.

15. Levi M, Levy M, Williams MD, Douglas I, Artigas A, Antonelli M, Wyncoll D, Janes J, Booth FV, Wang D, Sundin DP, Macias WL, Xigris and Prophylactic HepaRin Evaluation in Severe Sepsis (XPRESS) Study Group: Prophylactic heparin in patients with severe sepsis treated with drotrecogin alfa (activated). $\mathrm{Am} J$ Respir Crit Care Med 2007, 176:483-490. 